DOI:10.30842/ielcp230690152249

A. Corso

\title{
OPERA NOBILIA AT PARION
}

Статья посвящена истории и судьбе скульптур, созданных выдающимися древнегреческими мастерами и установленных на западе Малой Азии в Парионе: бронзовая статуя Геракла, выполненная Гегесием, мраморная статуя Эроса Праксителя, а также (возможно) бронзовая статуя Париса Евфранора. Автор исследует исторические события, на фоне которых эти шедевры создавались. Так, Геракл Гегесия рассматривается в контексте включения Париона в Делосский союз, возглавлявшийся Афинами, а Эрос Праксителя и Парис Евфранора - в связи с политикой сатрапа Фригии Артабаза.

Ключевые слова: древнегреческая скульптура, Фригия, Парион, Пракситель, Гегесий, Евфранор.

In this article the masterpieces made by renowned Greek artists and set up at Parion are considered. They are: 1. A bronze statue of Herakles by Hegesias; 2. A marble statue of Eros by Praxiteles; and 3. Probably a bronze statue of Paris by Euphranor. The historical backgrounds of these creations are researched. Hegesias' Herakles may be understood in the context of the inclusion of Parion in the Delian League led by Athens. On the contrary the Eros by Praxiteles and the Paris by Euphranor should be seen in the context of the monumental policy promoted by the Satrap of Hellespontine Phrygia, Artabazos. The fortune of these statues after the classical period is also followed.

The aim of this article is to study the masterpieces made by renowned masters and set up at Parion in antiquity. The first of these works we are aware of was the bronze statue of Herakles by Hegesias, probably of the early $5^{\text {th }} \mathrm{c}$. BC. This statue is recorded by Pliny, 34.781': Hagesiae in Pario colonia Hercules (scil.: laudatur). Probably this sculptor is the same Atticized as Hegesias by Quintilian, 12.10.72: Similis in statuis differentia. Nam duriora et Tuscanicis proxima Callon atque Hegesias, iam minus rigida Calamis, molliora adhuc supra dictis Myron fecit.

\footnotetext{
${ }^{1}$ About this passage, see $D N O$ I, 472, n. 554, with previous bibliography.

${ }^{2}$ About this passage, see $D N O$ I, 473, n. 555.
} 
Thus Hegesias is regarded to have flourished in the same age of Kallon, a well known Aeginetan bronze sculptor who was active around $500 \mathrm{BC}$, before Kalamis ${ }^{3}$.

This master is also known thanks to Lucian, Rhetorum praeceptor 9, who uses the Atticized form of the name too ${ }^{4}$ : the writer of Samosata in this passage is speaking of ancient rhetorical models which are not easy to copy and compares them to works of old style of Hegesias and of the environment of Kritios and Nesiotes, characterizing their works with 4 typically art critical

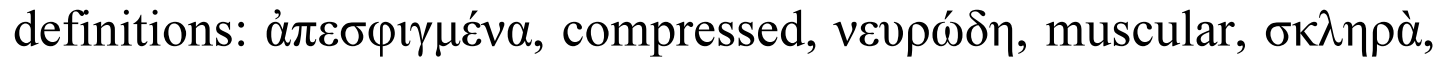

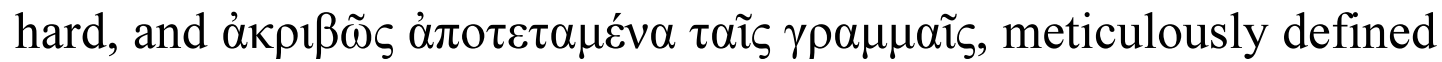
in their contours.

From these three passages it is fair to conclude that this bronze sculptor was originally a Dorian, which is why his name was Hagesias, perhaps an Aeginetan, of the environment of Kallon. Then he may have moved to Attica where, as it is argued from the above cited passage by Lucian, he became part of the environment of Critius and Nesiotes, probably in the 470s. His style was typically severe, as the definition by Lucian suggests.

Of course Herakles was an appropriate presence in Mysia, a region associated with the son of Herakles, Telephos ${ }^{5}$. Moreover Herakles was the hero of the first Trojan War: in that conflict, he vanquished and killed king Laomedon. This myth was dear to the culture of the early $5^{\text {th }}$ century $^{6}$ and may have been relevant to a polis so filled with Trojan memories as Parion.

\footnotetext{
${ }^{3}$ About Kallon, see, DNO I, 205-210 and 407-409. Although the team which compiled the new Overbeck distincts the bronze sculptor Kallon with two lambda from Aegina from the bronze sculptor also from Aegina Kalon with one lambda, I believe they are the same person. The chronology of Kallon is argued from the information provided by Pausanias, 2.32.5, that he was a pupil of Tektaios and Angelion and by the detail given by Pausanias, 3.18.7, that he was contemporary of Kanachos the Elder: thus he flourished in the late $6^{\text {th }} \mathrm{c}$. This period is consistent with the date of the two inscriptions signed by Kalon which is 500-490 BC. The old thesis that Hegesias is the same master also known as Hegias is no longer accepted because Hegesias is argued by the testimonies of Quintilian and Lucian to have flourished earlier than Hegias.

${ }_{5}^{4}$ About this passage see DNO I, 473-474, n. 556.

${ }^{5}$ See LIMC VII, 856-870, s. v. «Telephos» and Katsonopoulou 2008: 289301.

${ }^{6}$ See PI.N. 3.36-37; I. 6.27-31 and Fr. 140a Race. The eastern pediment of the temple of Aphaea at Aegina represented Herakles in the context of the
} 
Finally Paros, the homeland of Parion, was also important for the mythical history of Herakles, because this hero was thought to have stood on Paros during his quest for Hippolyte's belt, after which he went to Troy: this story was remembered in this period by Pindar, Fr. 140a Race 7 .

Parion joined the Delian league probably already in 478/477 BC, belonging to the Hellespontine district of the League ${ }^{8}$ : thus the statue of the hero who for the first time vanquished Troy may have been the usual transfer of the celebration of the recent victory against Persia into the myth ${ }^{9}$.

During the late $5^{\text {th }} \mathrm{c}$. BC, the poleis members of the Delian League had to pay heavy phoroi to the treasure of the league which was transferred to the Acropolis of Athens in $454 \mathrm{BC}^{10}$ : thus it is not surprising that Parion, as other poleis members of the league, is not known to have set up important masterpieces in town during these decades.

This stagnating situation changed with the peace of Antalkidas in 387/386 BC, when Parion fell to Persia and was included in the satrapy of the Hellespontine Phrygia, whose capital was Daskylion. The palace of the satraps at Daskylion and its surroundings, endowed with gardens and abundance of lush and thus apt to satisfy the pleasures of life, are described by Xenophon, $H G$ 4. $1.5^{11}$.

From 362 BC, the satrap of Daskylion was Artabazos, the son of Pharnabazos. He split from the Great King in $352 \mathrm{BC}$ and ruled his satrapy as independent kingdom until $345 \mathrm{BC}$, when he joined Persia again ${ }^{12}$.

He may have promoted the setting of works of famous Greek sculptors in important western centers of his satrapy, as the Hecatomnids did in south-western Anatolia. It is logical to suppose

first Trojan War (see Wuensche 2011: 205-213): thus this myth may have been familiar to a sculptor educated in the Aeginetan school.

${ }^{7}$ This episode is narrated by Apollod. 2.5.9.

${ }^{8}$ See Avram 2004: 991-992, entry no. 756.

${ }^{9}$ For the transposition of the victory upon the Persians to the realm of the myth in the Athenian culture of the $5^{\text {th }} \mathrm{c}$. BC, the bibliography is huge: see e. $g$. Hoelscher 2000: 287-320.

${ }_{11}$ About the Delio-Attic league see Scheibelreiter 2013.

11 About the court of this satrap, see Sarikaya 2015: 175-197. About the close relation of this court with Greece and in particular Athens, see TunaNoerling 2001: 109-122.

${ }^{12}$ See DNP 1, 53 and Sarikaya 2015: 175-197. 
that with his monumental policy he wanted to dignify his state and to give emphasis to the mythical history and cults of the region.

These monuments included a statue of Apollo with a mouse by Skopas for the sanctuary of Apollo Smintheus at Chryse (STRABO 13. 1.48604 and EuSTAT., Ad Homeri Iliadem 1. 39): this agalma may have been represented on local coins ${ }^{13}$. Apollo was the god who in the first song of the Iliad sent a plague to the Greek army settled near Troja (Homer, Iliad 1. 1-317). This observation betrays the patronage of a ruler who was on the side of the Trojans and not of the Greeks and wanted to establish his own state on the Trojan memory.

Moreover Praxiteles' bronze statue of Apollo Sauroktonos may perhaps have been set up at Apollonia ad Rhyndacum because he appears on local coins sometimes within a temple from Domitian until Gallien, thus for a very long period ${ }^{14}$.

The sinuous style of the teenage looking god and the soft rendering of skin and flesh make this statue a manifesto of the habrosyne of Asia Minor versus the muscular concept of young males which was typical of the Peloponnesian tradition.

Concerning Parion, two masterpieces were set up in this period in town. One of them was a marble statue of Eros by Praxiteles which is known thanks to Pliny, 36.22:

Eiusdem (scil.: Praxitelis) et alter (scil.: Cupido) nudus in Pario colonia Propontidis, par Veneri Cnidiae nobilitate et iniuria: adamavit enim Alcetas Rhodius atque in eo quoque simile amoris vestigium reliquit.

${ }^{13}$ See Calcani 2009: 71-72, n. 12, and 131, nn. 12-12a and DNO III: 434436, nn. 2303-2304. About the Smintheion, where Skopas' statue was set up, see Oezgunel 2012a: 274-287; 2012b: 137-153 and 2013.

${ }^{14}$ See Corso 2013: 22-65, no. 36. About the Sauroktonos, see DNO III: 108-112, nn. 1912-1913 and Bennett 2015: 135-138. The substitution of the tree-trunk with an Ionic column as support of Apollo on coins of Apollonia may have had the function of stressing the pertinence of the statue to a sanctuary and in particular to an Ionic temple. Sometimes the support of Apollo Sauroctonus on coins of Apollonia is a candelabrum, which may also have suggested the high sacrality of this peculiar statue (see Corso 2013: 49). The alternance between column and tree trunk in known also in the case of Apollo Lykeios (see Pochmarski-Nagele 1984: 77-105). Finally in Mysia a Doric column sometimes is placed at the side of Aphrodite (see Corso 2007: 91-92, fig. 60). 
Thus Pliny stresses the renown of the statue, which matches the importance of the cult of Eros at Parion, testified by Pausanias 9.27.1.

The mythical aition of this cult would lay in the legend that Paris spent his childhood at Parion, where he was honored with a statue and the tomb in the agora and to whom sacrifices and festivities were performed ${ }^{15}$.

Then even this statue gave emphasis to the Trojan heritage, in keeping with the consideration of the kingdom of Troy as the mythical antecedent of the satrapy of Artabazos.

Praxiteles' Eros at Parion is represented on coins of this polis (Fig. 1) and is recognized in the Kos type of Eros (Figs. 2-3), whose figure is very similar to the Eros on coins of Parion: ${ }^{16}$ again this mellephebos with his velvety skin and S shaped style expresses the value of the Ionian soft life style, opposed to the virile ideal of life of the Doric world.

The second important probably late classical statue in Parion represented Paris, as we know from Athenagoras, Legatio pro Christianis 26.3: it was bronze and set up in the agora near the supposed tomb of the Trojan hero, where public sacrifices and festivities in honor of the hero were held.

Since statues of Paris outside of any narrative context are rare, it is probable that this bronze statue of Paris coincides with the bronze Paris by Euphranor, lauded by Pliny, 34.77: Euphranoris Alexander Paris est, in quo laudatur quod omnia simul intellegantur, iudex dearum, amator Helenae et tamen Achillis interfector.

These three episodes tie this statue to the mythical history of the Troad. Moreover, the representation of Paris as slayer of Achilles reveals anti-Greek feelings: whoever patronized this statue sided with the Trojans against the Greeks and wanted to commemorate Paris' prevalence upon the greatest of Greek warriors. For this

\footnotetext{
15 The testimonia have been collected by Frisch 1983: 56-58. Athenagoras, Legatio pro Christianis 26.3 is the most important of these sources. Athenagoras certainly identifies the Alexander worshipped in the agora of Parion with Paris because he names him Dysparis ("unlucky Paris"), repeating the same nickname of Paris in Homer, Iliad 3. 39. Other testimonia about Paris as the founding hero of Parion are: Ammianus Marcellinus 22. 8. 4; Johannes Antiochenus, FHG M 4. 550. 23; Malalas 92 D; Suda, s. v. Parion; Cedrenus $216 \mathrm{~B}$ and Tzetzes, Antehomerica $57 \mathrm{f}$.

${ }_{17}^{16}$ See Corso 2013: 65-75, n. 37 and DNO III: 136-138, n. 32.

${ }^{17}$ About this statue, see DNO IV: 77-77, N. 2777.
} 
reason, this statue may have been an episode of satrapic patronage: this consideration strengthens the identification of Euphranor's Paris with the statue of this hero set up in the agora of Parion.

Since Parion is not far from Byzantion, the statue may have been the same bronze Paris brought to Constantinople and described by Nicetas Choniates, De statuis 2.5: the Trojan hero was standing, supposed to be near Aphrodite and about to handle the golden apple to the goddess ${ }^{18}$. It should be noted that even the Eros of Praxiteles may have been brought from Parion to Constantinople, because an epigram by Palladas (Anthologia Graeca 16. $207=$ DNO IV 136 N. 40) may have been composed for a new base of the statue, needed in AD IV c.

This Paris may be identified in the copyist tradition of the Borghese/Ludovisi/Hamburg type of youth with Phrygian hat who bears a sinuous style ${ }^{19}$ (Fig. 4) which is similar, although reversed, to that of the Sauroktonos. In this type the Trojan prince is resting on a tree trunk at his right side. His identity was revealed by his Phrygian hat as well as by the apple which he probably held in his right hand and which he was ready to give to the love goddess. The beauty of his body with velvety skin and his indolent sinuous stance also suggest the ethos of Paris, the hero gynaikomanes. His enchanted gaze may have conveyed to viewers his love for Helen. Finally, he may have held in his left hand his bow with which he killed Achilles. This creation reveals both the rhythmical research of the Polycleitan school and the typically Attic late classical concern for the soft appearance of the figure. Thus it fits the personality of Euphranor well, because this Isthmian artist shared research patterns both of the Peloponnesian school and of the Attic one. Thus even this type may have advertized the same androgynous ideal of youth of satrapic Asia Minor, suggestive of a sensual life style and opposed to the muscular athletic ideal of youth of mainland Greece.

Probably in the early Hellenistic times, a monumental altar for Artemis and Apollo Aktaios was set up, a work of the architect

18 Probably this bronze Paris stood in the Forum Constantini of Constantinople: see Bravi 2014: 262-266. It is not clear whether Aphrodite was also represented or her presence in front of Paris was left to the imagination of the viewer. In my opinion, the careful reading of this passage of Nicetas suggests the second possibility as the most probable.

${ }^{19}$ About this sculptural type, see Jentzen 1964: 241-256 and Todisco 1993: 92, figg. 191-193. 
Hermokreon: its large size puts it in the tradition of early Hellenistic Ionian large altars. This monument was regarded a marvel, was celebrated in the ancient tradition until late antiquity and was shown on coins already in the years after its completion ${ }^{20}$ : it is likely that the dedication of the important altar of the Artemision of Ephesos elicited the emulation of other sanctuaries of Artemis and Apollo along the coast of Asia Minor.

Pliny in the above quoted passage 36.22 specifies that a Rhodian named Alketas copulated with Praxiteles' Eros of Parion and left a stain on the statue similar to that left by another lover on a thigh of the Knidian Aphrodite ${ }^{21}$. The name Alketas is known on Rhodes thanks to a couple of inscriptions from Kamiros ${ }^{22}$ : from these two documents it is argued that a Rhodian Alketas lived in the early $2^{\text {nd }}$ c. BC and was a member of a family whose exponents are recorded both for holding the local damiourgia as well as public benefactors.

Since the period of flourishing of Alketas from Kamiros is the same of the reception of the sculptural type of the Eros of Parion in the visual culture of Rhodes ${ }^{23}$, (Fig. 3) it is possible that Alketas, with his fondness for this Eros, pioneered the practice of copying this type on the island.

It should be noticed that in the late $3^{\text {rd }} \mathrm{c}$. BC, the bronze sculptor Theudoros of Parion made portrait statues of important Rhodian dignitaries set up on Rhodes ${ }^{24}$. These close ties between Parion and Rhodes also help to explain the reception of the Parion's type of Eros on Rhodes.

The statues of Herakles by Hegesias, of Eros by Praxiteles and of Paris by Euphranor probably were recorded in writings of Hellenistic art critics because these three creations are mentioned also by Pliny the Elder in his sections of the books 34 and 36 devoted respectively to bronze and marble sculpture and it is well

\footnotetext{
${ }^{20}$ See Frisch 1983: 89-90, nn. 101-102 a-e and DNO V: 431-432, nn. 4040-4041.

${ }^{21}$ The recorded episodes of agalmatophilia between young men and the Knidian Aphrodite have been collected in Corso 2007: 40-49.

${ }_{22}^{22}$ See Martin Vazquez 1988, inscriptions nn. 242 and 249.

${ }^{23}$ This statement is based on the statuette in Parian marble from the necropolis of Rhodes at Rhodes, Archaeological Museum, N. E 498, to be dated in the early $2^{\text {nd }}$ c. BC: see Corso 2013: 112 , n. 531, no. 2.

${ }^{24}$ See Prignitz 2014: 676-679, nn. 3461-3464.
} 
known that this Latin writer took much of his information about Greek artists from previous Hellenistic art critics ${ }^{25}$.

The statue of Eros at Parion was imitated with variations sometimes during the late Hellenistic and Roman imperial times both in the Aegean world and at Rome ${ }^{26}$. The statue of Paris by Euphranor was also imitated with the Borghese/Ludovisi/Hamburg type, whose most important copies are dated in early Roman imperial times ${ }^{27}$.

Finally the Antonine period sees the renown of the philosopher of Parion Peregrinos ${ }^{28}$. It is likely that the fact to be the birthplace of one of the best established intellectuals of the time elicited the self esteem of the Parians: thus they began striking coins with miniature representations of their Praxitelean Eros ${ }^{29}$.

After the death of Peregrinus in 165, the bronze statue of this renowned neosophist was set up at Parion, as it is known from Athenagoras, Legatio pro Christianis 26.3-4, and was attributed oracular power.

Coin types bearing miniature copies of the Eros of Parion were struck also under Commodus, Alexander Severus, Otacilia Severa, Philip the Arab and eventually Aemilian ${ }^{30}$.

${ }_{26}^{25}$ About this assumption, see Tanner 2006: 235-246.

${ }^{26} \mathrm{I}$ am aware of the following variations of the Eros of Parion during the $1^{\text {st }} \mathrm{c} . \mathrm{BC}$ and $\mathrm{AD}{ }^{\text {st }} \mathrm{c} .: 1$. A marble statuette from the large peristyle of the Roman House at Kos, dated in the $1^{\text {st }} \mathrm{c}$. BC and kept at Kos, Archaeologi-

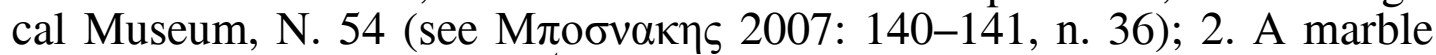
torso probably of the late $1^{\text {st }} \mathrm{c}$. BC, from Rome, once in the collection of the King of Spain Philip $5^{\text {th }}$, then in San Ildefonso, Palacio Real, then at Madrid, Museo del Prado, n. 12 E (see Schroeder 2004: 277-280, n. 155); 3. A marble statue of $\mathrm{AD} 1^{\text {st }} \mathrm{c}$., probably from Rome, perhaps from the Quirinal hill near Rospigliosi Palace and once decorating the Baths of Constantine, once in the Borghese Collection, then at Paris, Louvre, DAGER N. MR $140=$ Ma 345 (see Minozzi 2011: 368). See Corso 2013: 112-113, n. 531, n. 1-15.

${ }_{28}^{27}$ See Todisco 1993: figg. 191-193.

${ }^{28}$ About Peregrinos, see Pilhofer 2005.

${ }^{29}$ Praxiteles' Eros of Parion is represented on reverses of two AE coin types struck by Parion under Antonine Pius: see Filow 1909: 65. Still in the Antonine period, the marble copy of our Eros from Nikopolis ad Istrum is dated: it is kept at Sofia, National Archaeological Museum, N. 8410 (see Ivanov, von Buelow 2008: 56-57).

${ }^{30}$ These coin types are recorded by Corso 2013: 113, n. 531, nn. 10-14. 
With the decline of the neosophistic culture in the $3^{\text {rd }}$ quarter of the $3^{\text {rd }}$ c. BC, most Greek cities stopped exhibiting their masterpieces on their coins and Parium also abandoned this habit.

Finally, perhaps at the time of Constantine, the bronze statue of Paris may have been removed and brought to Constantinople, to the Forum Constantini, where it stood until 1204, when it was melted down (Nicetas Choniates, De statuis 2. 5) ${ }^{31}$. The removal of Praxiteles' Eros from Parion and his setting in the secunda Roma may also have happened, as it might be argued by the above cited epigram of Palladas.

\section{References}

$D N O=$ Kansteiner, S. et alii (Hrsg.). 2014: Der Neue Overbeck. Die antiken Schriftquellen zu den bilden den Künsten der Griechen. Bde. I-V, Berlin.

LIMC = Lexicon Iconographicum Mythologiae Classicae, Zürich; München; Düsseldorf, 1981-1999.

$D N P=$ Cancik, H., Schneider H. (Hrsg.). 1996-2003: Der neue Pauly. Bde. $1-16$, Stuttgart.

Avram, A. 2004: The Propontic Coast of Asia Minor. In: Hansen, M. H., Nielsen, T. H. (ed.). An Inventory of Archaic and Classical Poleis. Oxford, 974-999.

Bennett, M. 2015: An Original by Praxiteles? In: Settis, S. (a cura di). Serial/Portable Classic. Milan, 135-138.

Bravi, A. 2014: Griechische Kunstwerke im politischen Leben Roms und Konstantinopels. Berlin.

Calcani, G. 2009: Skopas di Paros, Roma.

Corso, A. 2007: The Art of Praxiteles. Vol. 2. Rome.

Corso, A. 2013: The Art of Praxiteles. Vol. 4. Rome.

Filow, B. 1909: Erosstatue aus Nicopolis ad Istrum. JdI, 60-73.

Fritsch, P. 1983: Die Inschriften von Parion. Bonn.

Hoeltscher, T. 2000: Feindwelten, Glueckswelten, Perser, Kentauren und Amazonen. Hoelscher, T. (Hrsg.). Gegenwelten. Munich, 287-320.

Ivanov, R., von Buelov, G. 2008: Thracia. Mainz am Rhein.

Jantzen, U. 1964: Der Paris des Euphranor. JdI 79, 241-256.

Katsonopoulou, D. 2008: Telephos Arkasides. In: Katsonopoulou, D. (ed.). Archilochos and his Age. Athens, 289-301.

Martin Vazquez, L. 1988: Inscripciones Rodias. Madrid.

Minozzi, M. 2011: Genio. In: Coliva, A. (a cura di). I Borghese e l'antico. Rome, 368.

Oezgunel, C. 2012a: The Smintheion Sanctuary. In: Oezdem F. (ed.). Canakkale. Istanbul, 274-287.

${ }^{31}$ See Bravi 2014: 266. 
Oezgunel, C. 2012b: Die Ergebnisse der neuen Ausgrabungen im Smintheion. In: Schulz, T. (Hrsg.). Dipteros und Pseudodipteros. Istanbul, 137-153.

Oezgunel, N. 2013: Smintheion. Istanbul.

Pilhofer, P. 2005: Lukian, Der Tod des Peregrinos. Darmstadt.

Pochmarski-Nagele, M. 1984: Zum Typus des Apollo Lykeios. OeJ 55, $77-105$.

Prignitz, S. 2014: Theudoros. DNO IV, 676-679.

Sarikaya, S. 2015: Artabazus's Role in the Dascylium Dynastic Systems. Olba 23, 175-197.

Scheibelreiter, P. 2013: Untersuchungen zur vertragsrechtlichen Struktur des Delisch-Attischen Seebundes, Vienna.

Schroeder, S. 2004: Katalog der antiken Skulpturen des Museo del Prado in Madrid, 2. Mainz am Rhein.

Tanner, J. 2006: The Invention of Art History in ancient Greece. Cambridge.

Todisco, L. 1993: Scultura greca del IV secolo. Milano.

Tuna-Noerling, Y. 200: Attic Pottery from Dascylium. In: Bakir, T. (ed.). Achaemenid Anatolia. Leiden, 109-122.

Wuensche, R. 2011: Kampfe um Troja. Lindenberg im Allgaeu.

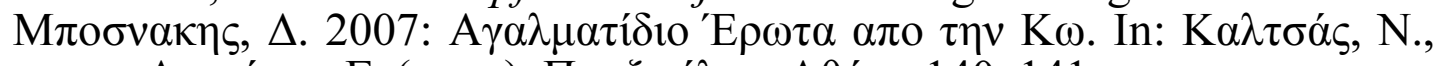

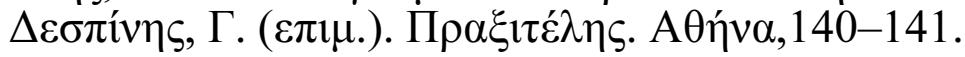

\section{A. Corso. Opera nobilia at Parion}

In this article the masterpieces made by renowned Greek artists and set up at Parion are considered. They are: 1. A bronze statue of Herakles by Hegesias; 2. A marble statue of Eros by Praxiteles; and 3. Probably a bronze statue of Paris by Euphranor. The historical backgrounds of these creations are researched. Hegesias' Herakles may be understood in the context of the inclusion of Parion in the Delian League led by Athens. On the contrary the Eros by Praxiteles and the Paris by Euphranor should be seen in the context of the monumental policy promoted by the Satrap of Hellespontine Phrygia, Artabazos. The history of these statues after the Classical period is also described.

Keywords: Greek sculpture, sculptors Hegesias, Praxiteles, Euphranor, Greek colonies, Phrygia, Parion. 


\section{PICTURES}

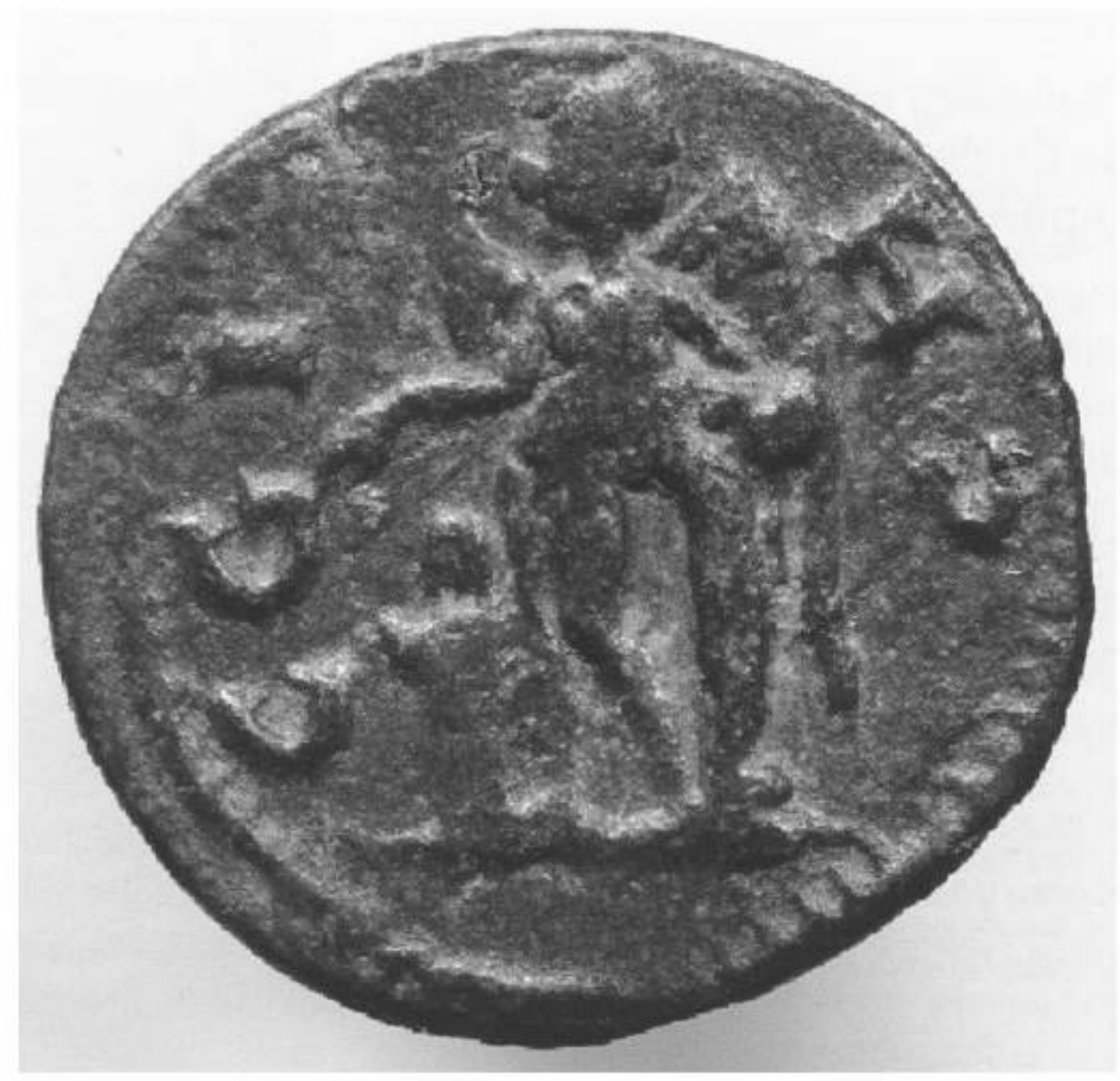

Fig. 1. AE coin struck by Parion under Aemilian, reverse. 


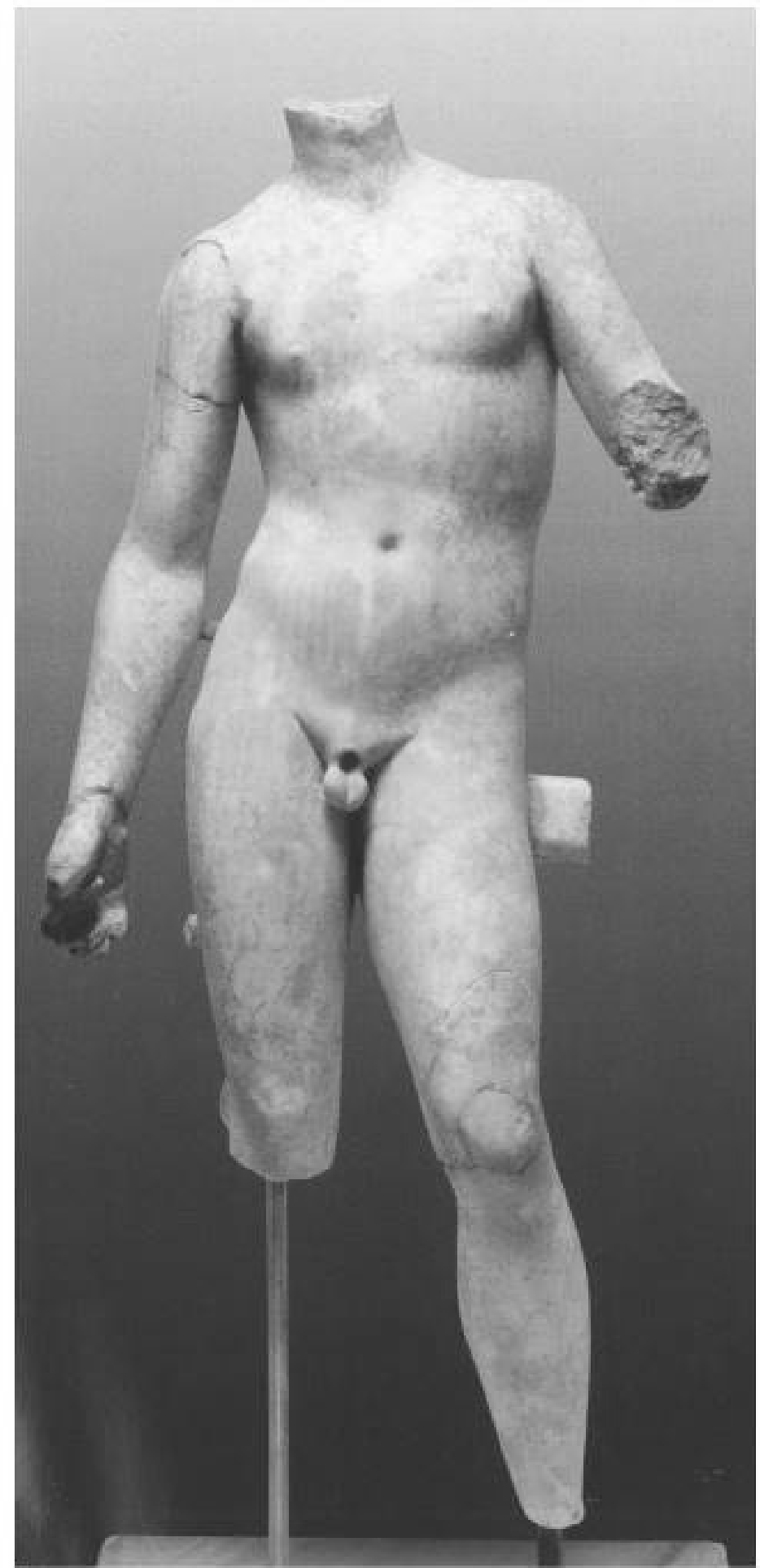

Fig. 2. Marble statuette of Eros from the Roman House of Kos, kept at Kos, Archaeological Museum. 


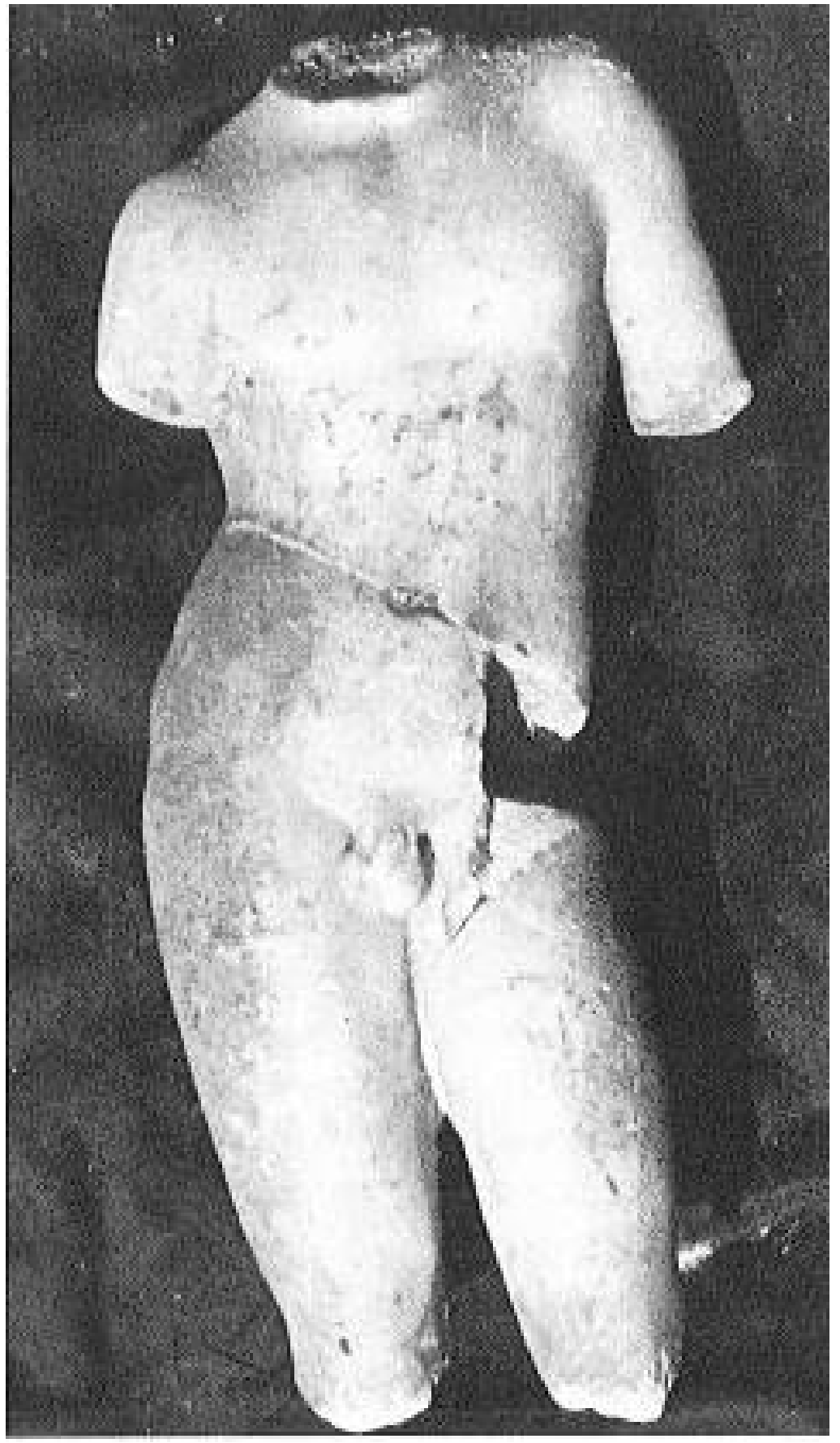

Fig. 3. Marble statuette of Eros from the necropolis of Rhodes, kept at Rhodes, Archaeological Museum. 


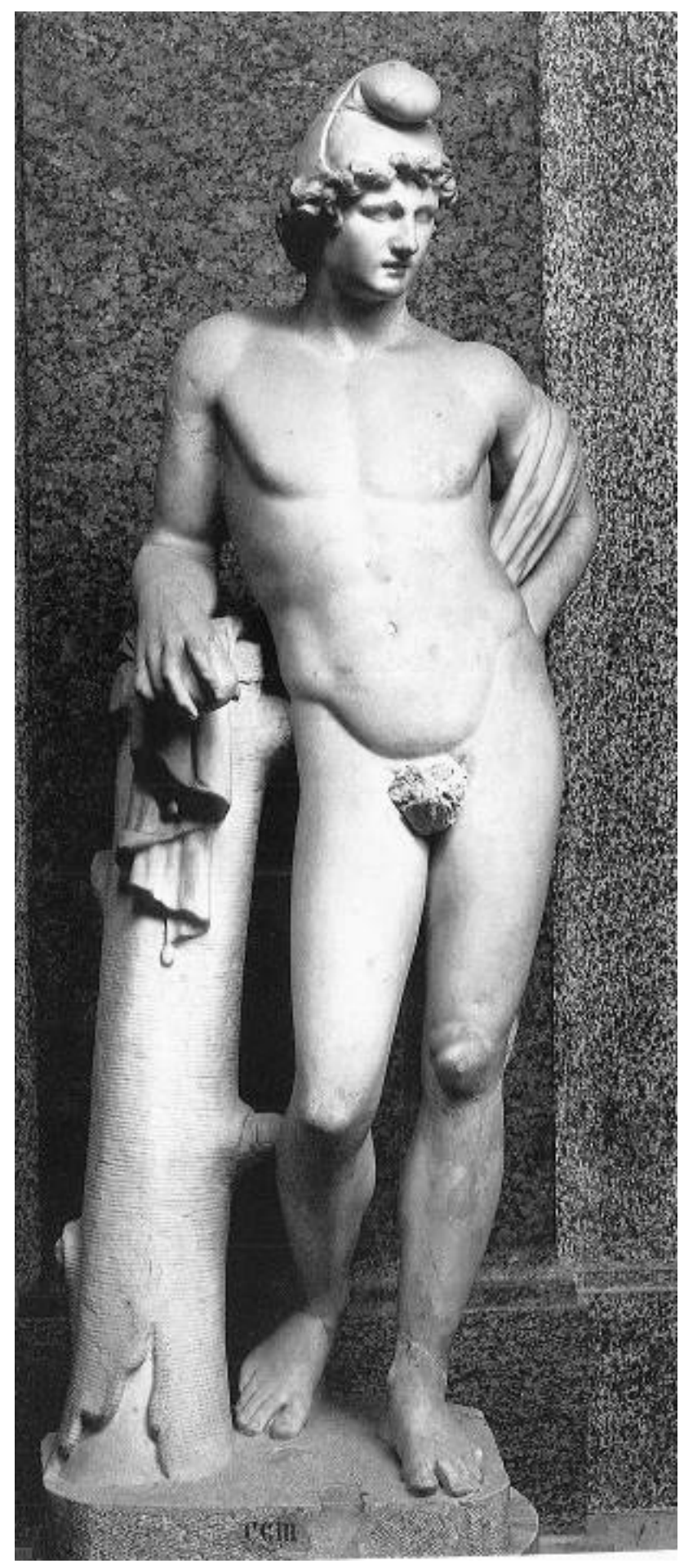

Fig. 4. Marble statue of Paris, Rome, Galleria Borghese. 